
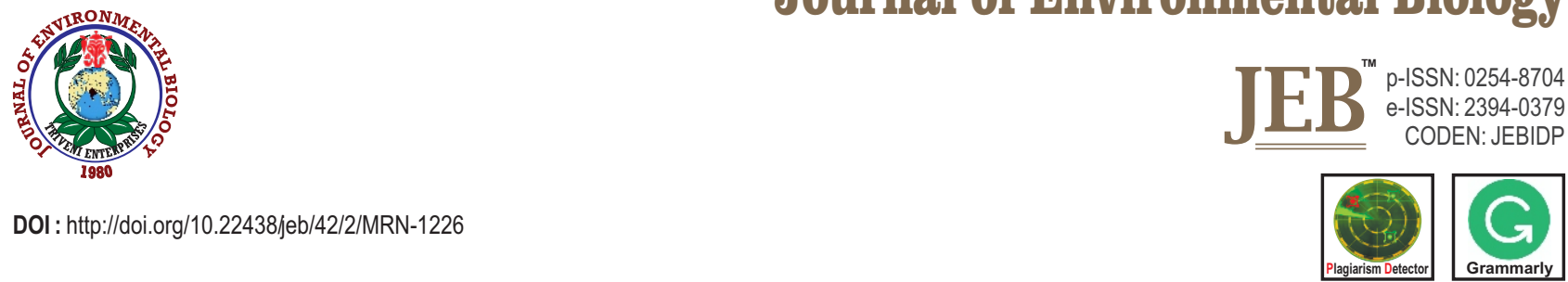

\title{
Response of soybean genotypes to iron limiting stress in calcareous vertisol under ambient and elevated $\mathrm{CO}_{2}$ and temperature conditions
}

\author{
Kiran Karthik Raj ${ }^{1,5}$, R.N. Pandey ${ }^{1 *}$, Bhupinder Singh ${ }^{2}$, M.C. Meena', A. Talukdar ${ }^{3}$ and D. Chakraborty ${ }^{4}$ \\ ${ }^{1}$ Soil Science and Agricultural Chemistry, ICAR-Indian Agricultural Research Institute, New Delhi-110012, India \\ ${ }^{2}$ Nuclear Research Laboratory, Centre for Environment Science and Climate ResilientAgriculture, ICAR-IARI, New Delhi-110 012 , India \\ ${ }^{3}$ Genetics, ICAR-Indian Agricultural Research Institute, New Delhi-110012, India \\ ${ }^{4}$ Agricultural Physics, ICAR-Indian Agricultural Research Institute, New Delhi-110012, India \\ ${ }^{5}$ Natural Resource Management, ICAR-Central Island Agricultural Research Institute, Port Blair-744 107, India \\ *Corresponding Author Email : rnpandeyssaciari@rediffmail.com
}

\section{Abstract}

Aim: To compare the relative performance of two contrasting genotypes of soybean to iron limiting conditions under ambient and elevated $\mathrm{CO}_{2}$ and temperature conditions.

Methodology: A pot culture experiment was performed using calcareous vertisol soil. The environmental factors viz. $\mathrm{CO}_{2}$ and temperature were combined and applied as a single factor with two levels: a- $\left[\mathrm{CO}_{2}+\mathrm{T}\right](400 \pm 10$ $\mu \mathrm{mol} \mathrm{mol}{ }^{-1}$, day/night temperature $\left.30^{\circ} \mathrm{C} / 22^{\circ} \mathrm{C}\right)$ and e- $\left[\mathrm{CO}_{2}+\mathrm{T}\right](610 \pm 10 \mu \mathrm{mol}$ $\mathrm{mol}^{-1}$, day/night temperature $34^{\circ} \mathrm{C} / 26^{\circ} \mathrm{C}$ ). Soybean genotype that differed in iron use efficiency was used as another factor and two contrasting genotypes were used as two levels viz. iron efficient and responsive (FeER) and iron inefficient and responsive (FeIR).

Results: The higher partial pressure of $\mathrm{CO}_{2}$ under elevated carbon dioxide and temperature condition $\left(\mathrm{PCO}_{2}=61.8 \mathrm{~Pa}\right)$ dissolved the native $\mathrm{CaCO}_{3}$ from calcareous vertisol soil and thereby resulted in higher $\mathrm{HCO}_{3}^{-}$ion concentration. The antagonistic interaction between $\mathrm{Fe}^{2+}$ with $\mathrm{HCO}_{3}^{-}$ion resulted in greater iron stress. As compared to ambient condition, seed yield was significantly reduced under more stressed e- $\left[\mathrm{CO}_{2}^{+} \mathrm{T}\right]$ condition and resulted in $\sim 1.4$ and $\sim 1.9$ times drop in FeER and FelR genotypes,

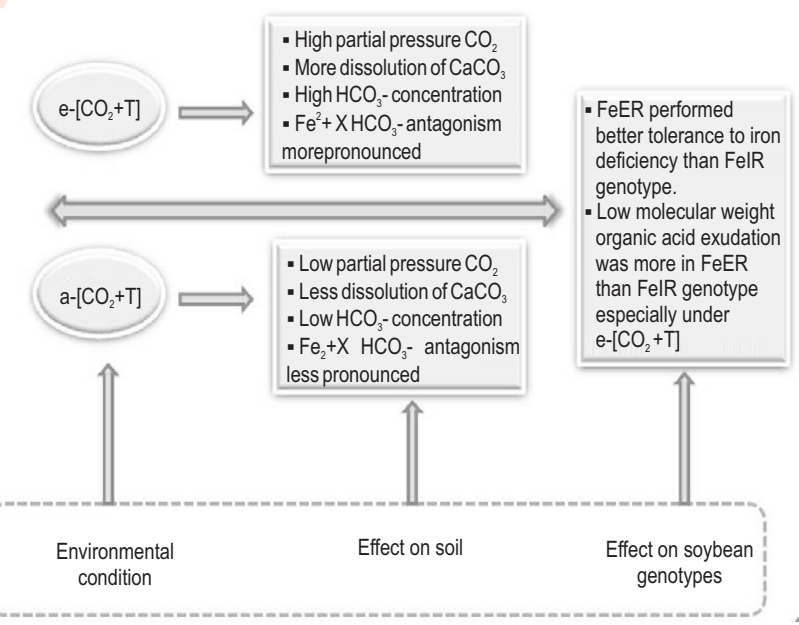
respectively. Iron efficient and responsive (FeER) genotype recorded an impressive performance, as compared to the iron inefficient and responsive (FelR) genotype, in counteracting iron deficiency stress, both under ambient and elevated conditions.

Interpretation: The intra-specific variability between soybean genotypes and their response to elevated $\mathrm{CO}_{2}$ and temperature can be exploited to remediate the emerging iron deficiency stress in soybean plants and suggest ways to structure the future breeding programmes to adapt to the climate change.

Key words: Calcareous vertisol, Chlorosis, Climate change, $\mathrm{CO}_{2}$, Soybean

How to cite : Raj, Kiran Karthik, R.N. Pandey, Bhupinder Singh, M.C. Meena, A. Talukdar and D. Chakraborty: Response of soybean genotypes to iron limiting stress in calcareous vertisol under ambient and elevated $\mathrm{CO}_{2}$ and temperature conditions. J. Environ. Biol., 42, 295-301 (2021). 


\section{Introduction}

Iron is an essential micronutrient required for many vital functions in the plants such as chlorophyll synthesis, photosynthesis and respiration (Vigani et al., 2009; Briat et al., 2015). It is a principal component in Fe-S cluster enzymes (Jeong and Connolly, 2009). Iron limiting stress is a major factor that constraints soybean production (Vasconcelos and Grusak, 2014; Liang et al., 2013). Iron deficiency chlorosis (IDC) is an abiotic nutritional stress, mainly observed on calcareous and high pH soils of arid and semi-arid agro-ecosystems, that affects $30 \%$ of the world's agricultural land (Mori, 1999). Soybean is an important oilseed crop, sensitive to iron deficiency stress and is a yield-limiting factor predominantly in calcareous soils (Lucena et al., 2007). All plants, except cereals and grasses, uptake $\mathrm{Fe}^{2+}$ by strategy I mechanism, while graminaceous plants uptake iron by siderophore-mediated strategy II mechanism. Soybean being a dicot plant, acquire iron by Strategy I mechanism, in which the plants induce an Iron-Stress Response (ISR) under iron deficient stress condition, which involves increase in acidification of rhizosphere, release of reductants, and organic acids at the root surface (Zocchi et al., 2007). Climate change is a reality that we are experiencing every part of the world. Ambient atmospheric $\mathrm{CO}_{2}$ would rise, from the current $400 \mu \mathrm{mol} \mathrm{mol}{ }^{-1}$ to $700 \mu \mathrm{mol} \mathrm{mol}{ }^{-1}$, and average air temperature by 1 to $4^{\circ} \mathrm{C}$ at the end of 2100 (O'Neill et al., 2017). It will adversely affect the crop production, environmental quality and its long term sustenance (Gray and Brady, 2016). Previous studies have revealed that the rate of average annual increase for $\mathrm{CO}_{2}$ is nearly $2 \mathrm{umol} \mathrm{mol}^{-1}$ (Shiogama et al., 2016). Elevated $\mathrm{CO}_{2}$ will have significant direct effects on crop as well as environment (Ravi et al., 2019; Bhatt et al., 2010; Ziska, 2008a). Besides, increasing atmospheric $\mathrm{CO}_{2}$ concentration increases the mean global temperature (Houghton, 2001).

Regulation of Fe stress response under climate change scenario and the underlying mechanisms are not well understood. However, the intra-specific variability in growth and yield response to elevated $\mathrm{CO}_{2}$ has been reported for wheat (Ziska, 2008b), rice (Gillespie et al., 2011; Shimono, 2011) and soybean (Sicher et al., 2010; Ziska and Bunce, 2000) crops. Till date, the most effective strategy for combating iron deficiency chlorosis has been the use of iron-efficient genotypes (Wang et al., 2008). It is widely recognised that the selection of promising cultivars of a crop will be an important aspect of adaptation in the face of a changing climate (Tausz et al., 2013; Semenov and Halford, 2009). Meagre research has been conducted on the effect of climate change on IDC in calcareous vertisol soil, thus, keeping in view of the above, this study was carried out to investigate effect of elevated $\mathrm{CO}_{2}$ and temperature on differential response of soybean genotypes to iron deficiency stress.

\section{Materials and Methods}

Plant material: Two contrasting soybean genotypes differs in iron efficiency viz. NRC-45 (iron efficient and responsive category, FeER) and IC-18734 (iron inefficient and responsive category, FeIR), identified from an earlier screening experiment of fifty genetically diverse soybean genotypes (Raj et al., 2019a), were used in the present study. The genotypes were obtained from the Soybean Breeding Laboratory of the Division of Genetics and Plant Breeding of ICAR-Indian Agricultural Research Institute, New Delhi, India. Genotypes were characterized by comparing the relative performance of $\mathrm{C}-14$ exudation and dry matter produced (under iron deficient condition to iron sufficient condition). Selection criteria were defined based on the fact that root exudation is primarily involved in improving Fe uptake under iron limiting stress condition (Zocchi et al., 2007). Besides, the overall performance in terms of chlorophyll content, Fe content in shoot, and the correlation between them were also considered.

Pot culture experiment: A pot culture experiment was conducted in a two factorial completely randomised design using calcareous Vertisol in the glass house of National Phytotron Facility at the ICAR-Indian Agricultural Research Institute, New Delhi. The first factor is the environmental condition viz. $\mathrm{CO}_{2}$ and temperature applied as a single factor with two levels: a- $\left[\mathrm{CO}_{2}+\mathrm{T}\right]$ $\left(400 \pm 10 \mu \mathrm{mol} \mathrm{mol}{ }^{-1}\right.$, day/night temperature $\left.30^{\circ} \mathrm{C} / 22^{\circ} \mathrm{C}\right)$ and e$\left[\mathrm{CO}_{2}+\mathrm{T}\right]\left(610 \pm 10 \mu \mathrm{mol} \mathrm{mol}{ }^{-1}\right.$, day/night temperature $\left.34^{\circ} \mathrm{C} / 26^{\circ} \mathrm{C}\right)$. Soybean genotype that differ in iron use efficiency was used as the second factor and two contrasting genotypes viz. FeER and FelR were used as two levels. Five replications were maintained for each treatment combinations. Pots measuring $15.2 \mathrm{~cm}$ diameter $\mathrm{x}$ $14.2 \mathrm{~cm}$ height were filled with $1 \mathrm{~kg}$ calcareous Vertisol. Two seeds were sown per pot and uniform crop management practices were followed for all the pots. Recommended dose of fertilizers containing 10-16-15 mg N-P-K kg-1 soil, $18.2 \mathrm{mg} \mathrm{S}$ and $12.5 \mathrm{mg} \mathrm{ZnSO}_{4} \mathrm{~kg}^{-1}$ soil were applied to all the pots.

Soil analyses: Soil was sampled through a soil tube, taking a vertical core to the full depth of the pot 30 days after sowing (Conkbr, 1918). Total $\mathrm{CaCO}_{3}$ and bicarbonate in the soil sample was determined as per the method described by Rowell (1994). Low molecular weight organic acids were estimated by the method of Dong et al. (2004) with slight modification. Soil sample $(5 \mathrm{~g})$ from each pot was extracted with $50 \mathrm{ml}$ of $0.05 \mathrm{mM} \mathrm{CaCl}_{2}$ solution in $100 \mathrm{ml}$ conical flask. The samples were then injected to High Performance Liquid Chromatography (Agilent Technologies, 1200 Infinity Series, Santa Clara, CA, USA) reverse phase column Hamilton PRP-1 was used with $0.1 \%$ orthophosphoric acid as mobile phase and the flow rate was $1 \mathrm{ml}$ min. $^{-1}$, at wavelength $210 \mathrm{~nm}$ using VWD (variable wavelength detector). Available iron, manganese, zinc and copper were extracted by DTPA extractant and determined with Atomic Absorption Spectrometer (Lindsay and Norwell, 1978).

Iron deficiency chlorosis (IDC) visual score: The extent of IDC severity was measured by two methods viz. visual scoring and soil-plant analysis development (SPAD), 30 days after planting. Scoring was performed by a panel of three trained staffs. Visual score of plant was evaluated based on the severity in the appearance of chlorotic symptoms on terminal leaflet of recently 
matured fully expanded trifoliate compound leaf. Scoring system described by Srinives et al. (2010) was adopted in this study with scale ranged between 1 to $5 ; 1$ (no yellowing), 2 (slight), 3 (moderate), 4 (intense coverage) and 5 (necrotic spots and severe yellowing).

Leaf greenness (SPAD): Leaf greenness was measured using SPAD-502 meter (MINOLTA, Tokyo) in five plants of each treatment combination, and mean was used to characterize IDC symptom. SPAD measurements were recorded from four spots of terminal leaflet of recently matured fully expanded trifoliate compound leaf, 2 each on the left and right of the midrib. The measurement was performed immediately after visual scoring.

Seed and stover yield: On maturity, pods were separated from shoot, dried and labelled. Weight was taken in an analytical digital laboratory balance (Citizon, Model CG-203, India). The seed and stover yield recorded were expressed in g plant ${ }^{-1}$.

Iron concentration in shoot: Powdered plant sample was predigested with concentrated nitric acid followed by di-acid digestion $\left(\mathrm{HNO}_{3}: \mathrm{HClO}_{4}\right.$ in 3:1 ratio). The volume of digested samples was made to $50 \mathrm{ml}$ and the concentration of iron in the sample was measured with Atomic Absorption Spectrophotometer (Jackson, 1973).

Statistical analyses: The dependent variables were compared against the fixed factors using General Linear Models Programme. Statistical significance between treatment combinations were made for genotype $x$ environment effect $(G x$ $E$ effect) using SAS 9.2 (SAS Institute Inc. 2009. SAS OnlineDoc®9.2. Cary, NC: SAS Institute Inc.).

\section{Results and Discussion}

Environmental conditions exerted significant influence on $\mathrm{CaCO}_{3}, \mathrm{HCO}_{3}-$ and DTPA extractable iron content in soil (Environment effect $p<0.0001$, Table 1). Across the treatment combinations, DTPA extractable iron content in soil varied from $3.96 \mathrm{mg} \mathrm{kg}^{-1}\left(\mathrm{e}-\left[\mathrm{CO}_{2}+\mathrm{T}\right]\right)$ to $4.13 \mathrm{mg} \mathrm{kg}^{-1}\left(\mathrm{a}-\left[\mathrm{CO}_{2}+\mathrm{T}\right]\right)$ for FeER, and from $3.22 \mathrm{mg} \mathrm{kg}^{-1}\left(\mathrm{e}-\left[\mathrm{CO}_{2}+\mathrm{T}\right]\right)$ to $3.68 \mathrm{mg} \mathrm{kg}^{-1}\left(\mathrm{a}-\left[\mathrm{CO}_{2}+\mathrm{T}\right]\right)$ for FelR genotype. Further, the genotype effect ( $G$ effect), environment effect ( $E$ effect) and $G \times E$ interaction effect were significant for DTPA-Fe with $p<0.0001, p<0.0001$ and $p=$ 0.0038 , respectively. Further, the environmental condition has significant influence on $\mathrm{CaCO}_{3}$ and $\mathrm{HCO}_{3}$-content in the soil with $\mathrm{p}$ $<0.0001$ (Table 1). The higher partial pressure of $\mathrm{CO}_{2}$ under elevated carbon dioxide and temperature condition $\left(\mathrm{PCO}_{2}=61.8\right.$ $\mathrm{Pa}$ ) dissolved the native $\mathrm{CaCO}_{3}$ from calcareous vertisol soil, and thereby resulted in higher $\mathrm{HCO}_{3}$-ion concentration (Table 1).

The antagonistic interaction between $\mathrm{Fe}^{2}+$ with $\mathrm{HCO}_{3}$ - ion had resulted in greater iron stress and thus, shoot iron content was low in e- $\left[\mathrm{CO}_{2}+\mathrm{T}\right]$ grown plant than $\mathrm{a}-\left[\mathrm{CO}_{2}+\mathrm{T}\right]$ grown plant (Table 2). The results revealed that calcareous soil caused iron deficiency chlorosis (IDC), especially for FelR genotypes grown, even under less stressed conditions a- $\left[\mathrm{CO}_{2}+\mathrm{T}\right]$ (Table 1). Under iron limiting stress, the inter-veinal tissue of leaf became yellowish with green veins, which eventually resulted in reduced growth and yield (Table 2). The observation was in tandem with the findings of Prathet et al. (2012), who reported higher average IDC visual score and lower SPAD reading in mungbean grown under iron deficient condition. When the plants were subjected to more stressed condition, i.e., e- $\left[\mathrm{CO}_{2}+\mathrm{T}\right]$, the chlorotic symptom aggravated, especially FelR genotype indicated that there exists significant interaction between genotype and environment. The observation corroborated well with the report of Myers et al. (2014) that elevated $\mathrm{CO}_{2}$ significantly reduces Fe content in plant as compared to ambient condition.

Across the treatments, the main effects of genotype (G), environment $(E)$ and their interaction ( $G \times E$ effect) were significantly influenced on IDC visual score, SPAD reading and Fe concentration in the shoot (Table 2). The genotype FeIR recorded $\sim 1.06$ and $\sim 1.61$ times significantly higher visual score than FeER under a- $\left[\mathrm{CO}_{2}+\mathrm{T}\right]$ and $\mathrm{e}-\left[\mathrm{CO}_{2}+\mathrm{T}\right]$ conditions $(\mathrm{G} \times \mathrm{E}$ effect $\mathrm{p}$ $<0.0001$ ). Additionally, the average performance of genotypes on IDC visual score was $\sim 1.5$ times greater for e- $\left[\mathrm{CO}_{2}+\mathrm{T}\right]$ grown plants than for a- $\left[\mathrm{CO}_{2}+\mathrm{T}\right]$ grown plants (E effect $p<0.0001$ ) with an average values of 1.59 (FeER) and 2.57 (FeIR) under e$\left[\mathrm{CO}_{2}+\mathrm{T}\right]$ vs. 1.36 (FeER) and 1.44 (FelR) under a-[CO $\left.\mathrm{CO}_{2}+\mathrm{T}\right]$ condition. Among all the treatment combinations, SPAD reading was significantly higher for FeER genotype grown under a$\left[\mathrm{CO}_{2}+\mathrm{T}\right]$ with the value 38.9 and least 21.7 for FelR under e$\left[\mathrm{CO}_{2}+\mathrm{T}\right]$ condition. Under iron deficiency stress, the chlorophyll biosynthesis gets disturbed, which in turn resulted in reduced photosynthesis. Higher plants, when exposed to iron starved condition, exhibited altered chloroplast structure and reduced photosynthetic rate, which has disturbed chlorophyll biosynthesis and eventually resulted in stunted growth (Vigani et al., 2009; Briat et al. 2015). Seed and stover yields were significantly affected by the effect of genotype $(G)$, environment $(E)$ and their interaction ( $\mathrm{G} \times \mathrm{E}$ ) as depicted in Table 2.

In comparison with a- $\left[\mathrm{CO}_{2}+\mathrm{T}\right]$ condition, the seed yield was significantly reduced under more stressed e- $\left[\mathrm{CO}_{2}+\mathrm{T}\right]$ condition and resulted in $\sim 1.38$ times and $\sim 1.98$ times drop in FeER and FelR genotypes, respectively ( $G \times E$ effect; $p<0.0106)$ with values $6.98 \mathrm{~g} \mathrm{plant}^{-1}(\mathrm{FeER})$ and $4.09 \mathrm{~g} \mathrm{plant}^{-1}$ (FeIR) vs. 9.66 $\mathrm{g} \mathrm{plant}^{-1}$ (FeER) and $7.87 \mathrm{~g} \mathrm{plant}^{-1}$ (FeIR). With respect to stover yield, on an average, FeER recorded $\sim 1.38$ times and $\sim 1.14$ times significantly higher yield than FelR under a- $\left[\mathrm{CO}_{2}+\mathrm{T}\right]$ and e$\left[\mathrm{CO}_{2}+\mathrm{T}\right]$ conditions, respectively, with values of $21.2 \mathrm{~g} \mathrm{plant}^{-1}$ (FeER) and 18.6 g plant ${ }^{-1}$ (FeIR) vs. $19.7 \mathrm{~g} \mathrm{plant}^{-1}$ (FeER) and 14.3 g plant $t^{-1}$ (FelR) (G effect $p<0.0001$, E effect $p<0.0001, G \times E$ effect $p<0.0090$ ). Such intra-specific variability in yield response to elevated carbon dioxide has been reported in wheat (Ziska, 2008b), rice (Gillespie et al., 2011; Shimono, 2011) and soybean (Sicher et al., 2010; Ziska and Bunce, 2000) crops. IDC sensitive parameters such as dry matter produced, chlorophyll content and 


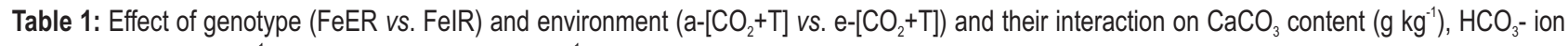
concentration $\left(\mathrm{mmol} \mathrm{kg}^{-1}\right)$, DTPA extractable $\mathrm{Fe}\left(\mathrm{mg} \mathrm{kg}^{-1}\right)$ in calcareous vertisol at 30 days after sowing

\begin{tabular}{lllll}
\hline $\begin{array}{l}\text { Environmental } \\
\text { condition (E) }\end{array}$ & $\begin{array}{l}\text { Genotype } \\
\text { (G) }\end{array}$ & $\begin{array}{l}\mathrm{CaCO}_{3} \text { content } \\
\text { in soil }\left(\mathbf{g ~ k g}^{-1}\right)\end{array}$ & $\begin{array}{l}\mathrm{HCO}_{3^{-}} \text {ion conc. } \\
\text { in soil }\left(\mathbf{m m o l ~ k g}^{-1}\right)\end{array}$ & $\begin{array}{l}\text { DTPA-Fe } \\
\left(\mathbf{m g ~ k g}^{-1}\right)\end{array}$ \\
\hline $\mathrm{a}-\left[\mathrm{CO}_{2}+\mathrm{T}\right]$ & $\mathrm{FeER}$ & $173.0 \pm 1.16^{\mathrm{a}}$ & $4.21 \pm 0.02^{\mathrm{a}}$ & $4.13 \pm 0.06^{\mathrm{a}}$ \\
$\mathrm{PCO}_{2}=40.5 \mathrm{~Pa}$ & $\mathrm{FelR}$ & $170.9 \pm 0.78^{\mathrm{a}}$ & $4.28 \pm 0.04^{\mathrm{a}}$ & $3.68 \pm 0.04^{\mathrm{c}}$ \\
$\mathrm{e}-\left[\mathrm{CO}_{2}+\mathrm{T}\right]$ & $\mathrm{FeER}$ & $164.0 \pm 1.06^{\mathrm{b}}$ & $7.13 \pm 0.02^{\mathrm{b}}$ & $3.96 \pm 0.04^{\mathrm{b}}$ \\
$\mathrm{PcO}_{2}=61.8 \mathrm{~Pa}$ & $\mathrm{FelR}$ & $162.6 \pm 2.07^{\mathrm{b}}$ & $7.09 \pm 0.03^{\mathrm{b}}$ & $3.22 \pm 0.03^{\mathrm{d}}$ \\
\hline
\end{tabular}

Mean \pm standard error of five replications are presented; different letters indicates significant difference between the treatment combinations using $p$ value associated with the pre-planned comparison of respective Least Square (LS) means at $p<0.05$ using SAS. $p$ value indicate the significance; ${ }^{* * *} p<$ $0.001 ;{ }^{* *} p<0.01 ;{ }^{*} p<0.05 ;$ ns (not significant) at $p>0.05$

Table 2: Effect of genotype (FeER vs. FeIR), environment $\left(\mathrm{a}-\left[\mathrm{CO}_{2}+\mathrm{T}\right]\right.$ vs. e- $\left.\left[\mathrm{CO}_{2}+\mathrm{T}\right]\right)$ and their interaction on IDC visual score, SPAD reading, Fe concentration in shoot, seed and stover yield of soybean plants grown in calcareous vertisol

\begin{tabular}{|c|c|c|c|c|c|c|}
\hline $\begin{array}{l}\text { Environmental } \\
\text { condition (E) }\end{array}$ & $\begin{array}{l}\text { Genotype } \\
\text { (G) }\end{array}$ & $\begin{array}{l}\text { IDC } \\
\text { scores }\end{array}$ & $\begin{array}{l}\text { SPAD } \\
\text { reading }\end{array}$ & $\begin{array}{l}\text { Fe concentration } \\
\text { in shoot }\end{array}$ & $\begin{array}{l}\text { Seed yield } \\
\left.\text { (g plant }^{-1}\right)\end{array}$ & $\begin{array}{l}\text { Stover yield } \\
\left.\text { (g plant }^{-1}\right)\end{array}$ \\
\hline \multirow{2}{*}{$\mathrm{a}-\left[\mathrm{CO}_{2}+\mathrm{T}\right]$} & FeER & $1.36 \pm 0.02^{\mathrm{a}}$ & $38.9 \pm 0.44^{\mathrm{a}}$ & $46.3 \pm 0.53^{\mathrm{a}}$ & $9.66 \pm 0.36^{a}$ & $21.2 \pm 0.31^{a}$ \\
\hline & FelR & $1.44 \pm 0.03^{b}$ & $36.3 \pm 0.51^{b}$ & $43.8 \pm 0.67^{b}$ & $7.87 \pm 0.04^{b}$ & $18.6 \pm 0.69^{b}$ \\
\hline \multirow{2}{*}{$\mathrm{e}-\left[\mathrm{CO}_{2}+\mathrm{T}\right]$} & FeER & $1.59 \pm 0.02^{c}$ & $29.6 \pm 0.78^{c}$ & $39.6 \pm 0.59^{c}$ & $6.98 \pm 0.10^{c}$ & $19.7 \pm 0.25^{b}$ \\
\hline & FelR & $2.57 \pm 0.03^{d}$ & $21.7 \pm 0.80^{d}$ & $32.3 \pm 0.44^{d}$ & $4.09 \pm 0.02^{d}$ & $14.3 \pm 0.52^{c}$ \\
\hline \multirow{3}{*}{$P$ value } & Genotype (G) & $<0.0001^{* \star *}$ & $<0.0001^{* * *}$ & $<0.0001^{* * *}$ & $<0.0001^{* * *}$ & $<0.0001^{* * *}$ \\
\hline & Environ. (E) & $<0.0001^{* * *}$ & $<0.0001^{* * *}$ & $<0.0001^{* * *}$ & $<0.0001^{* * *}$ & $<0.0001^{* * *}$ \\
\hline & $G \times E$ & $<0.0001^{* * *}$ & $<0.0009^{* * *}$ & $0.0006^{* * *}$ & $0.0106^{*}$ & $0.0090^{* *}$ \\
\hline
\end{tabular}

Mean \pm standard error of five replications are presented; different letters indicates significant difference between the treatment combinations using $p$ value associated with the pre-planned comparison of respective Least Square (LS) means at $p<0.05$ using SAS. $p$ value indicate the significance; ${ }^{* * \star} p<$ $0.001 ;{ }^{* *} p<0.01 ;{ }^{*} p<0.05 ;$ ns (not significant) at $p>0.05$

root exudation significantly varied between genotypes. Such differential response by iron efficient and inefficient genotypes of soybean is well recognized and attributed to the inherent variability to tolerate the iron limiting stress (Raj et al., 2019a, 2020; Vasconcelos and Grusak, 2014).

It was observed that both FeER and FelR genotypes exuded significantly higher amount of low molecular weight organic acids under e- $\left[\mathrm{CO}_{2}+\mathrm{T}\right]$ condition than a- $\left[\mathrm{CO}_{2}+\mathrm{T}\right]$ condition (Fig. 1), revealing that genotype $(G)$, environment (E) and their interaction $(G \times E)$ have significant influence on low molecular weight organic acids. Soybean acquire iron through strategy I mechanism and the iron acquiring ability depends on the amount of low molecular weight organic acid exuded (Raj et al., 2019b; Liang et al., 2013; Jeong and Connolly, 2009). Among organic acids, the exudation citric and oxalic acids were more pronounced, followed by malic acid. Under ambient condition (a$\left[\mathrm{CO}_{2}+\mathrm{T}\right]$ ), when compared with FelR genotype, FeER exhibited significantly higher exudation of oxalic acid ( 1.85 fold), citric acid (1.75 fold) and malic acid ( 1.57 fold). Further, because of the greater iron stress experienced under $\mathrm{e}-\left[\mathrm{CO}_{2}+\mathrm{T}\right]$ condition, FeER genotype exuded significantly higher amount of low molecular weight organic acids (oxalic acid - 2.31 fold, citric acid - 1.99 fold, malic acid - 2.12 fold increase) as compared to FelR grown under
$\mathrm{a}-\left[\mathrm{CO}_{2}+\mathrm{T}\right]$ condition. The main effect caused by genotype and environmental factors were highly significant for citric, oxalic and malic acid exudations ( $G$ effect and $E$ effect $p<0.0001$ for all). Conversely, neither genotype $(p=0.9221)$ nor environment $(p=$ 0.9221) was found to exert significant influence on exudation of tartaric acid. Across the treatment combinations, exudation of citric acid was found significantly higher in FeER $(24.8 \mu \mathrm{mol} \mathrm{kg}$ $\left.{ }^{1}\right)$ under $\mathrm{e}-\left[\mathrm{CO}_{2}+\mathrm{T}\right]$ than FeIR $\left(12.4 \mu \mathrm{mol} \mathrm{kg}{ }^{-1}\right)$ grown under a$\left[\mathrm{CO}_{2}+\mathrm{T}\right]$; exudation of significantly higher oxalic acid with the values $26.7 \pm 0.5 \mu \mathrm{mol} \mathrm{kg}{ }^{-1}$ (FeER under e- $\left[\mathrm{CO}_{2}+\mathrm{T}\right]$ ) as compared to $11.5 \pm 0.6 \mu \mathrm{mol} \mathrm{kg}{ }^{-1}$ (FelR under a- $\left[\mathrm{CO}_{2}+\mathrm{T}\right]$ ); exudation of significantly higher malic acid with the values $14.9 \pm 0.3 \mu \mathrm{mol} \mathrm{kg}{ }^{-1}$ (FeER under $\mathrm{e}-\left[\mathrm{CO}_{2}+\mathrm{T}\right]$ ) as compared to 7.0 $\pm 0.1 \mu \mathrm{mol} \mathrm{kg}{ }^{-1}$ (FelR under a- $\left[\mathrm{CO}_{2}+\mathrm{T}\right]$ ). Furthermore, within each set of treatment of $\left[\mathrm{CO}_{2}+\mathrm{T}\right]$, exudation of citric, oxalic and malic acids as regulatory iron stress responses were more pronounced in FeER than FelR genotype (Fig. 1).

Under iron limiting stress condition, being Strategy I plant, the Iron-Stress Response (ISR) is more pronounced in FeER genotype, therefore, the exudation of organic acids by root is more favoured (Zocchi et al., 2007). It was worth noting that FeER genotype showed an impressive tolerance to iron stress by 

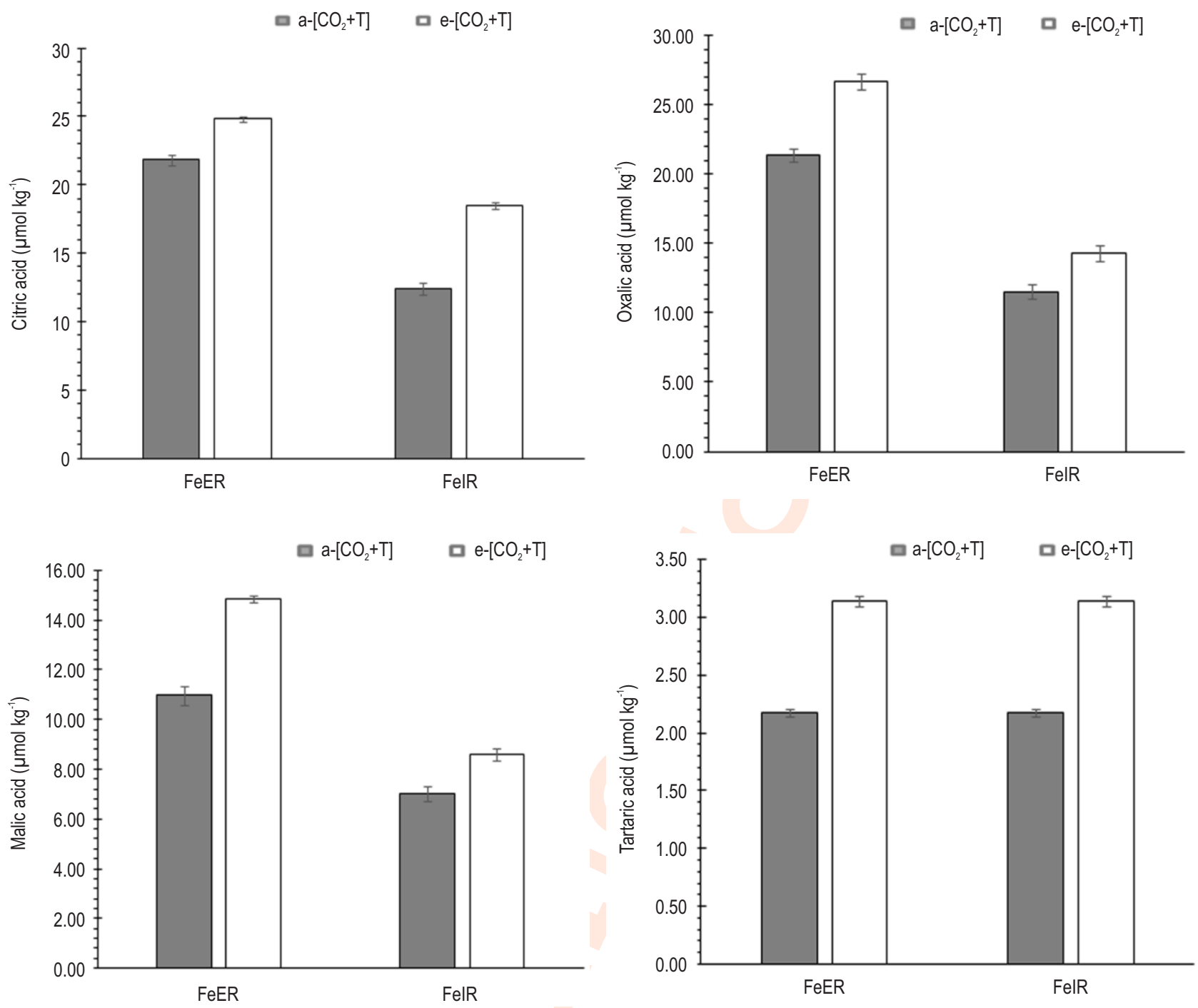

Fig. 1: Effect of different factors viz. genotype of soybean (FeER vs. FeIR), environment $\left(a-\left[\mathrm{CO}_{2}+\mathrm{T}\right]\right.$ vs. e- $\left.\left[\mathrm{CO}_{2}+\mathrm{T}\right]\right)$ and their interaction on low molecular weight organic acid concentration in the soils grown.

exuding higher amount of low molecular weight organic acids (Fig. 1), especially with respect to IDC visual score, SPAD reading, shoot iron concentration, seed and stover yield (Table 2), than FeIR under elevated condition. Further, it also implies that FeER could be better resilient to climate change and perform better than FelR genotype. Ainsworth et al. $(2004,2008)$ reported that soybean yield stimulated by 0 to $35 \%$ from least to most responsive cultivars of soybean per $100 \mu^{-1}$ increase in $\left[\mathrm{CO}_{2}\right]$ over current $\left[\mathrm{CO}_{2}\right]$. However, a decreasing trend in seed and stover yield under e- $\left[\mathrm{CO}_{2}+\mathrm{T}\right]$ condition was observed (Table 1). Such reduction in yield under elevated $\mathrm{CO}_{2}$ and temperature conditions has been reported by Xiong et al. (2017), which might be associated with reduced photosynthetic rate coupled with higher respiration. Long-term exposure to elevated $\mathrm{CO}_{2}$ can reduce carboxylation and photosynthetic acclimation through feedback inhibition (Seneweera et al., 2002; Crafts-Brandner and Salvucci, 2000). Lobell and Asner (2003) reported that, for rise in every degree of ambient air temperature, corn and soybean yields decreased by $\sim 17 \%$. Further, reports revealed that the reproductive phase is more susceptible to temperature stress than the vegetative phase (Sánchez et al., 2014; Krishnan et al., 2011). Thus, under e- $\left[\mathrm{CO}_{2}+\mathrm{T}\right]$ condition, the present observation holds true for greater reduction in seed yield than stover yield (Table 2). The study also revealed that FeER genotype tolerated iron deficiency stress to a greater extent than FelR genotype.

Iron efficient and responsive (FeER) genotype recorded an impressive tolerance to iron limiting stress, as compared to 
iron inefficient and responsive (FelR) genotype, especially under more stressful e- $\left[\mathrm{CO}_{2}+\mathrm{T}\right]$ condition. Within each set of treatment of environmental conditions $\left[\mathrm{CO}_{2}+\mathrm{T}\right]$, the exudation of citric, oxalic and malic acids as regulatory iron stress response mechanism was more pronounced in FeER than FelR genotype. Thus, the interpretation based on the experiment revealed that FeER could be more resilient to the climate change and perform better than FeIR genotype. The intra-specific variability between contrasting genotypes and their response to elevated $\mathrm{CO}_{2}$ and temperature can be exploited to remediate emerging $\mathrm{Fe}$ deficiency in soybean and suggests ways to structure the future breeding programmes under climate change scenario.

\section{Acknowledgment}

The authors are grateful to the International Plant Nutrition Institute, USA; University Grant Commission, India; Indian Council of Agricultural Research (ICAR), New Delhi and National Phytotron Facility (NPF), New Delhi, India for necessary support.

\section{Add-on Information}

Authors' contribution: Kiran Karthik Raj: Conception and overall conduct of the experiment, data aquisition, statistical analysis, interpretation, drafting of manuscript; R.N. Pandey: Study conception and design, technical assistance, statistical expertise, supervision; Bhupinder Singh: Provision of experimental materials, data acquisition, critical revision of manuscript; M.C. Meena: Technical guidance, data acquisition, critical revision of manuscript; $A$. Talukdar: Supervision and set up of experiment, critical revision of manuscript; D. Chakraborty: Technical guidance, advisory support, critical revision of manuscript.

Research content: The research content is original and has not been published elsewhere

\section{Ethical approval: NotApplicable}

Conflict of interest: The authors declare that there is no conflict of interest.

\section{Data from other sources: NotApplicable}

Consent to publish: All authors agree to publish the paper in Journal of Environmental Biology.

\section{References}

Ainsworth, E.A., A. Rogers, R. Nelson and S.P. Long: Testing the "source-sink" hypothesis of down-regulation of photosynthesis in elevated $\left[\mathrm{CO}_{2}\right]$ in the field with single gene substitutions in Glycine max. Agric. For. Meteorol., 122, 85-94 (2004).
Ainsworth, E.A., C. Beier and C. Calfapietra: Next generation of elevated $\left[\mathrm{CO}_{2}\right]$ experiments with crops: A critical investment for feeding the future world. Plant Cell Environ., 31, 1317-1324 (2008).

Bhatt, R.K., M.J. Baig, H.S. Tiwari and R. Sharmila: Growth, yield and photosynthesis of Panicum maximum and Stylosanthes hamata under elevated $\mathrm{CO}_{2}$. J. Environ. Biol., 31, 549-552 (2010).

Briat, J.F., C. Dubos and F. Gaymard: Iron nutrition, biomass production and plant product quality. Trends Plant Sci., 20, $33-40$ (2015).

Conkbr, S.D.: Soil acidity as affected by moisture conditions of the soil. J. Agric. Res., 15, 321 (1918).

Crafts-Brandner, S.J. and M.E. Salvucci: Rubisco activase constrains the photosynthetic potential of leaves at high temperature and $\mathrm{CO}_{2}$. Proc. Natl. Acad. Sci., 97, 13430-13435 (2000).

Dong, D., X. Peng and X. Yan: Organic acid exudation induced by phosphorus deficiency and/or aluminium toxicity in two contrasting soybean genotypes. Physiol. Plant, 122, 190-199 (2004).

Gillespie, K.M., A. Rogers and E.A. Ainsworth: Growth at elevated ozone or elevated carbon dioxide concentration alters antioxidant capacity and response to acute oxidative stress in soybean (Glycine max). J. Exp. Bot., 62, 2667-2678 (2011).

Gray, S.B. and S.M. Brady: Plant developmental responses to climate change. Dev. Biol., 419, 64-77 (2016).

Houghton, J.: The science of global warming. Interdiscip. Sci. Rev., 26, 247-257 (2001).

Jackson, M.L.: Soil Chemical Analysis. Prentice Hall (India) Pvt. Ltd., New Delhi (1973).

Jeong, J. and E.L. Connolly: Iron uptake mechanisms in plants: Functions of the FRO family of ferric reductases. Plant Sci., 176, 709-714 (2009).

Krishnan, P., B. Ramakrishnan, K.R. Reddy and V.R. Reddy: Hightemperature effects on rice growth, yield and grain quality. Adv. Agron., 111, 87-206 (2011).

Liang, C., M.A. Piñeros, J. Tian, Z. Yao, L. Sun, J. Liu, J. Shaff, A. Coluccio, L.V. Kochian and H. Liao: Low pH, aluminum and phosphorus coordinately regulate malate exudation through GmALMT1 to improve soybean adaptation to acid soils. Plant Physiol., 161, 1347-1361 (2013).

Lindasy, W.L. and W.A. Norvell: Development of DTPA soil test for zinc, iron, manganese and copper. Soil Sci. Soc. Am. J., 42, 421-428 (1978).

Lobell, D.B. and G.P. Asner: Climate and management contributions to recent trends in US agricultural yields. Science, 299, 1032 (2003).

Lucena, C., F.J. Romera, C.L. Rojas, M.J. García, E. Alcántara and R. Pérez-Vicente: Bicarbonate blocks the expression of several genes involved in the physiological responses to Fe deficiency of Strategy I plants. Funct. Plant Biol., 34,1002-1009 (2007).

Mori, S.: Iron acquisition by plants. Curr. Opin. Plant Biol., 2, 250-253 (1999).

Myers, S.S., A. Zanobetti, I. Kloog, P. Huybers, A.D. Leakey, A.J. Bloom, E. Carlisle, L.H. Dietterich, G. Fitzgerald, T. Hasegawa and N.M. Holbrook: Increasing $\mathrm{CO}_{2}$ threatens human nutrition. Nature, $\mathbf{5 1 0}$, 139 (2014).

O'Neill, B.C., M. Oppenheimer, R. Warren, S. Hallegatte, R.E. Kopp, H.O. Portner, R. Scholes, J. Birkmann, W. Foden, R. Licker, K.J. Mach: IPCC reasons for concern regarding climate change risks. Nat. Clim. Change, 7, 28-37 (2017).

Prathet, P., P. Somta and P. Srinives: Mapping QTL conferring resistance to iron deficiency chlorosis in mungbean [Vigna radiate (L.) Wilczek]. Field Crops Res., 137, 230-236 (2012).

Raj, K.K., R.N. Pandey, B. Singh, A. Talukdar, M.C. Meena and K.A. Chobhe: Evidences for the use of ${ }^{14} \mathrm{C}$ content in the root exudates as a novel application of radiocarbon labelling for screening iron 
deficiency tolerance of soybean (Glycine $\max$ (L.) Merr.) genotypes. J. Radioanal. Nucl. Chem., 326, 487-496 (2020).

Raj, K.K., R.N. Pandey, B. Singh and A. Talukdar: ${ }^{14} \mathrm{C}$ labelling as a reliable technique to screen soybean genotypes (Glycine max (L.) Merr.) for iron deficiency tolerance. J. Radioanal. Nucl. Chem., 322, 655-662 (2019a).

Raj, K.K., R.N. Pandey, B. Singh, M.C. Meena and A. Talukdar: Mobilization of iron from calcareous vertisol to minimize iron deficiency chlorosis of soybean (Glycine max (L.) Merr.). J. Ind. Soc. Soil Sci., 67, 351-359 (2019b).

Ravi, V., S.J. More, R. Saravanan, G. Byju, M. Nedunchezhiyan, A.A. Devi and K.P. Nair: Potential increase in photosynthetic response of taro (Colocasia esculenta L.) to photon flux density and elevated $\mathrm{CO}_{2}$. J. Environ. Biol., 40, 111-118(2019).

Rowell, D.L.: Soil Science: Methods and Applications. Prentice Hall, Harlow (1994).

Sánchez, B., A. Rasmussen and J.R. Porter: Temperatures and the growth and development of maize and rice:A review. Glob. Chang. Biol., 20, 408-417 (2014).

Semenov, M.A. and N.G. Halford: Identifying target traits and molecular mechanisms for wheat breeding under a changing climate. J. Exp. Bot., 60, 2791-804 (2009).

Seneweera, S.P., O. Ghannoum, J.P. Conroy, K. Ishimaru, M. Okada, M. Lieffering, H.Y. Kim and K. Kobayashi: Changes in source-sink relations during development influence photosynthetic acclimation of rice to free air $\mathrm{CO}_{2}$ enrichment (FACE). Funct. Plant Biol., 29, 947-955 (2002).

Shimono, $\mathrm{H}$.: Rice genotypes that respond strongly to elevated $\mathrm{CO}_{2}$ also respond strongly to low planting density. Agric. Ecosyst. Environ., 141, 240-243 (2011).

Shiogama, H., D. Stone, S. Emori, K. Takahashi, S. Mori, A. Maeda, Y. Ishizaki and M.R. Allen: Predicting future uncertainty constraints on global warming projections. Sci. Rep., 6, 18903 (2016).

Sicher, R., J. Bunce and B. Matthews: Differing responses to carbon dioxide enrichment by a dwarf and a normal-sized soybean cultivar may depend on sink capacity. Can. J. Plant Sci., 90, 257-264 (2010).

Srinives, P., R. Kitsanachandee, T. Chalee, W. Sommanas and S. Chanprame: Inheritance of resistance to iron deficiency and identification of AFLP markers associated with the resistance in mungbean (Vigna radiata (L.) Wilczek). Plant Soil, 335, 423-437 (2010).

Tausz, M., S. Tausz-Posch, R.M. Norton, G.J. Fitzgerald, M.E. Nicolas and S. Seneweera: Understanding crop physiology to select breeding targets and improve crop management under increasing atmospheric $\mathrm{CO}_{2}$ concentrations. Environ. Exp. Bot., 88, 71-80 (2013).

Vasconcelos, M.W. and M.A. Grusak: Morpho-physiological parameters affecting iron deficiency chlorosis in soybean (Glycine max L.). Plant Soil, 374, 161-172 (2014).

Vigani, G., D. Maffi and G. Zocchi: Iron availability affects the function of mitochondria in cucumber roots. New Phytol., 182, 127-136 (2009).

Wang, J., P.E. McClean, R. Lee, R.J. Goos and T. Helms: Association mapping of iron deficiency chlorosis loci in soybean (Glycine max L. Merr.) advanced breeding lines. Theor. Appl. Genet., 116, 777 787 (2008).

Xiong, D., X. Ling, J. Huang and S. Peng: Meta-analysis and doseresponse analysis of high temperature effects on rice yield and quality. Environ. Exp. Bot., 141, 1-9 (2017).

Ziska, L.H. and J.A. Bunce: Sensitivity of field-grown soybean to future atmospheric $\mathrm{CO}_{2}$ : Selection for improved productivity in the $21^{\text {st }}$ century. Funct. Plant Biol., 27, 979-984 (2000).

Ziska, L.H.: Rising atmospheric carbon dioxide and plant biology: Overlooked paradigm. DNA Cell Biol., 27, 165-172 (2008a).

Ziska, L.H.: Three-year field evaluation of early and late 20th century spring wheat cultivars to projected increases in atmospheric carbon dioxide. Field Crops Res., 108, 54-59 (2008b).

Zocchi, G., P. De Nisi, M. Dell'Orto, L. Espen and P.M. Gallina: Iron deficiency differently affects metabolic responses in soybean roots. J. Exp. Bot., 58, 993-1000 (2007). 